historyczną i obywatelską. Szczególną uwagę poświęcono problemowi wiedzy i umiejętności ucznia oraz zagadnieniom związanym z działalnością wychowawczą szkoły.

Sekcja II, której przewodniczyli prof. Adam Winiarz, prof. Roman Pelczar, ks. prof. Edward Walewander, kontynuując problematykę działalności oświatowej zakonu pijarów, zajęła się tradycjami nauczania zakonu. Podczas jej obrad odniesiono się do programu edukacyjnego Stanisława Konarskiego na tle współczesnych teorii pedagogicznych. Przedstawiono wychowanie dziewcząt w ujęciu ks. A.M. Prokopowicza, wpływ szkół pijarskich na szkoły parafialne oraz organizację $\mathrm{i}$ funkcjonowanie szkolnictwa pijarskiego na centralnych ziemiach polskich w połowie XIX w.

$\mathrm{Na}$ zakończenie konferencji dokonano jej podsumowania wskazując, że tematyka skupiała się wokół spraw związanych zarówno z działalnością edukacyjną zakonu pijarów, jak i problemów współczesnej dydaktyki. Liczny udział w konferencji osób zajmujących się przeszłością zakonu pijarów i jego rolą pozwolił na wymianę opinii i doświadczeń związanych $\mathrm{z}$ badaniami $\mathrm{w}$ tych dziedzinach. Poruszano podczas niej tematykę związaną z wkładem polskich pijarów w rozwój polskiej oświaty, jak też kultury i sztuki. Udział gości zagranicznych pozwolił na poszerzenie jej o podobne kwestie dotyczące działalności zakonu pijarów na terenie Czech i Słowacji. W trakcie obrad podjęto próbę omówienia skutków ostatniej reformy polskiej oświaty, szczególnie w odniesieniu do nauczania historii, dokonując porównania założeń reformy $\mathbf{z}$ ich realizacją.

Organizatorzy, dziękując uczestnikom konferencji, zapowiedzieli publikację referatów.

Dariusz Szewczuk

\title{
Konferencja naukowa nt. „Opieka nad dzieckiem w Polsce - trady- cja i współczesność", 23 października 2007
}

W dniu 23 października 2007 r. w murach Pogotowia Opiekuńczego w Gdańsku odbyła się konferencja naukowa nt. „Opieka nad dzieckiem w Polsce - tradycja i współczesność". Konferencję zorganizował Zakład Historii Nauki, Oświaty i Wychowania Instytutu Pedagogiki Uniwersytetu Gdańskiego oraz Pogotowie Opiekuńcze im. Karola Olgierda Borchardta w Gdańsku. Celem konferencji było przybliżenie polskich tradycji w zakresie opieki nad dzieckiem oraz podjęcie dyskusji na temat współczesnego systemu instytucjonalnej opieki nad najmłodszymi członkami społeczeństwa i kierunkami jego przeobrażeń. Ponadto zamierzeniem organizatorów było uświetnienie obchodów 60-lecia Pogotowia Opiekuńczego w Gdańsku, które jest jedną z najstarszych placówek opiekuńczych $\mathrm{w}$ tym mieście. Problematyka zaproponowana przez organizatorów skłoniła do przybycia na konferencję pracowników naukowo-dydaktycznych Uniwersytetu Gdańskiego, Akademii Pomorskiej w Słupsku oraz Kolegium Karkonoskiego w Jeleniej Górze, a także byłych i obecnych pracowników Pogotowia Opiekuńczego w Gdańsku oraz jego dobroczyńców.

Zebranych na konferencji gości w imieniu organizatorów uroczyście przywitali: dr Andrzej Kołakowski z Uniwersytetu Gdańskiego oraz mgr Grzegorz Barczewski - dyrek- 
tor Pogotowia Opiekuńczego w Gdańsku. Wyrazili oni zadowolenie ze spotkania praktyków zajmujących się opieką nad dzieckiem oraz ludzi nauki podejmujących tę problematykę w badaniach naukowych. Ponadto uznali, że dyskusja tych dwóch podmiotów jest bardzo cenna, gdyż pogłębia rozumienie problemu opieki nad dzieckiem zarówno w sferze teorii, jak i praktyki oraz może być początkiem długotrwałego i owocnego dialogu. W konferencji, poprowadzonej przez prof. dr hab. Lecha Mokrzeckiego z Uniwersytetu Gdańskiego, głos zabrało dziewięciu prelegentów. W uroczystość włączyli się także wychowankowie Pogotowia Opiekuńczego w Gdańsku, którzy pod kierunkiem Elżbiety Dawidowskiej przygotowali program wokalno-taneczny. Obecność podopiecznych gdańskiej placówki oprócz doznań artystycznych miała także przypomnieć zebranym o tym, czyje dobro powinno być zawsze najwyższą we wszelkich działaniach związanych $\mathrm{z}$ instytucjonalną opieką nad dzieckiem.

Wystąpienia prelegentów można podzielić na trzy kategorie tematyczne: opieka nad dzieckiem w perspektywie ogólnopolskiej, regionalnej i prowadzona stricte w Pogotowiu Opiekuńczym w Gdańsku. Do pierwszej grupy referatów należały wystąpienia pracowników naukowo-dydaktycznych Uniwersytetu Gdańskiego: dr hab. Krzysztofa Jakubiaka nt. „Opieka nad macierzyństwem: matką i dzieckiem w II Rzeczpospolitej”, dr hab. Romualda Grzybowskiego zatytułowane „Dziecko i rodzina w świetle założeń komunistycznej teorii wychowania w Polsce w latach 1945-1956" oraz dr A. Kołakowskiego „Momenty przełomowe w polityce opiekuńczej okresu PRL”. Dr hab. K. Jakubiak w swoim wystąpieniu m.in. przybliżył zebranym prawno-organizacyjne uwarunkowania działań opiekuńczych z okresu II Rzeczpospolitej, analizując zapisy ustawy o opiece społecznej z 1923 r. dotyczące małych dzieci i matek. Referat wygłoszony przez dr hab. R. Grzybowskiego ukazał miejsce i rolę rodziny w założeniach ideologii komunistycznej oraz przedstawił konsekwencje całkowitego podporządkowania opieki i wychowania interesom politycznym totalitarnego państwa. Dr A. Kołakowski w swoim wystąpieniu zwrócił uwagę na związki przełomów w polityce opiekuńczej z przełomami politycznymi doby PRL.

Do wystąpień, których tematyka oscylowała wokół opieki nad dzieckiem w regionie zaliczyć można referat dr Danuty Apanel z Akademii Pomorskiej w Słupsku nt. „Rola instytucji pozarządowych w opiece nad dzieckiem na Pomorzu Środkowym w latach 1945-2005", w którym prelegentka m.in. podkreśliła zakres i znaczenie działalności prowadzonej przez Caritas i TPD. Kolejnym wystąpieniem analizującym opiekę nad dzieckiem w wymiarze regionalnym był referat wygłoszony przez dr Elżbietę Zieję z Kolegium Karkonoskiego w Jeleniej Górze nt. „Opieka nad dzieckiem na przełomie wieków na Dolnym Śląsku”. Prelegentka oprócz omówienia systemu organizacyjnego opieki nad dzieckiem na wspominanym obszarze podkreśliła także, że mimo niżu demograficznego w Polsce ciągle wzrasta liczba dzieci kierowanych do opieki instytucjonalnej oraz że ważną rolę w jej prowadzeniu odgrywają organizacje pozarządowe i fundacje. W wystąpieniu „Opieka nad dzieckiem w powiecie lęborskim (1945-2005)” mgr Telimena Ryta z Akademii Pomorskiej w Słupsku przedstawiła historię powiatu lęborskiego oraz działalność prowadzoną przez placówki opiekuńcze dla dzieci na jego terenie.

Rozważania nad działalnością Pogotowia Opiekuńczego w Gdańsku zainicjował referat mgr Anny Paszkowskiej z Uniwersytetu Gdańskiego zatytułowany „Z badań nad Po- 
gotowiem Opiekuńczym w Gdańsku w latach 1946-1989". Wystąpienie to m.in. przybliżyło zebranym trudności, na jakie natrafiają próby ustalenia dokładnej daty powstania Pogotowia Opiekuńczego w Gdańsku. O przeszłości gdańskiej placówki opiekuńczej mówiła także Pani Maria Biesiekierska, córka Anny Biesiekierskiej - osoby, która w latach 1950-1965 zarządzała Pogotowiem Opiekuńczym w Gdańsku. Pani M. Biesiekierska w wystąpieniu zatytułowanym „Wspomnienie o Annie Biesiekierskiej" nie tylko zaprezentowała postać swej matki i historię rodziny, ale omówiła także kilka problemów (dotykających sfery moralności i ideologii) związanych z codziennym kierowaniem placówką opiekuńczą w polskiej rzeczywistości doby PRL. Referat mgr G. Barczewskiego nt. „Pogotowie Opiekuńcze - dziś i jutro" przybliżył zebranym aktualne zadania placówki oraz główne problemy związane $\mathrm{z}$ ich realizacją. Prelegent w swoim wystąpieniu poruszył równieź kwestię zmian i tendencji rozwojowych w polityce opiekuńczej w Polsce i na terenie miasta Gdańska. Konferencję zamknęła prezentacja multimedialna „Dylematy 'wartości' w pracy z dzieckiem". Ten ponadczasowy problem w niebanalny sposób został opracowany przez: Marka Guzika, Małgorzatę Miłobęcką-Kamińską oraz Ewę Wilk - pracowników Pogotowia Opiekuńczego w Gdańsku.

Anna Paszkowska

\section{Ogólnopolska Konferencja Naukowo-Metodyczna „Akademicka Burza Mózgów - czyli o aktywizujących metodach nauczania" historii wychowania, Gdańsk, 23-25 listopada 2007 roku}

Początek XXI w., po okresie dynamicznego rozwoju szkolnictwa wyższego w Polsce lat 90. XX w., przyniósł w środowisku akademickim refleksje nad jakością oferty edukacyjnej. Problem ten mocno podkreślają również liczne dokumenty oświatowe o charakterze strategicznym. Wskazują one na konieczność szerszego zastosowania w procesie dydaktycznym metod aktywizujących. Zatem w szkolnictwie wyższym wypracowanie wysokiej jakości edukacji w znacznej mierze opierać się będzie na aktywnych, nowoczesnych metodach przeźywania oraz przekazywania wiedzy i wartości społecznych.

Wychodząc z tego założenia pracownicy Zakładu Historii Nauki, Oświaty i Wychowania oraz Koło Naukowe Historyków Edukacji Wydziału Nauk Społecznych Uniwersytetu Gdańskiego zorganizowali Ogólnopolską Konferencję Naukowo-Metodyczną pod hasłem „Akademicka burza mózgów - czyli o aktywizujących metodach nauczania”, która odbyła się dniach 23-25 listopada 2007 r. w Gdańsku.

To naukowe spotkanie, w myśl koncepcji organizatorów, w głównej swojej części przyjęło formę warsztatów. W związku z tym, liczba uczestników z góry została ograniczona do 20 osób. Warsztaty zgromadziły przedstawicieli nauki z 6 ośrodków naukowych w Polsce oraz aktywne grono studentek i absolwentek Uniwersytetu Gdańskiego.

Celem warsztatów było podjęcie dyskusji na temat metodyki nauczania historii wychowania w zakresie problematyki celów kształcenia we współczesnym szkolnictwie 